Marquette University

e-Publications@Marquette

Biological Sciences Faculty Research and

Publications

Biological Sciences, Department of

$1-2008$

\title{
Tertiary Climate Change and the Diversification of the Amazonian Gecko Genus Gonatodes (Sphaerodactylidae, Squamata)
}

Tony Gamble

Marquette University, anthony.gamble@marquette.edu

Andrew M. Simons

University of Minnesota

Guarino R. Colli

Universidade de Brasília

Laurie J. Vitt

University of Oklahoma

Follow this and additional works at: https://epublications.marquette.edu/bio_fac

Part of the Biology Commons

\section{Recommended Citation}

Gamble, Tony; Simons, Andrew M.; Colli, Guarino R.; and Vitt, Laurie J., "Tertiary Climate Change and the Diversification of the Amazonian Gecko Genus Gonatodes (Sphaerodactylidae, Squamata)" (2008).

Biological Sciences Faculty Research and Publications. 743.

https://epublications.marquette.edu/bio_fac/743 
Marquette University

e-Publications@Marquette

\section{Biology Faculty Research and Publications/College of Arts and Sciences}

This paper is NOT THE PUBLISHED VERSION; but the author's final, peer-reviewed manuscript. The published version may be accessed by following the link in the citation below.

Molecular Phylogentics and Evolution, Vol. 46, No. 1 (January 2008) : 269-277. DOI. This article is (C) Elsevier and permission has been granted for this version to appear in e-Publications@Marquette. Elsevier does not grant permission for this article to be further copied/distributed or hosted elsewhere without the express permission from Elsevier.

\section{Tertiary Climate Change and the Diversification of the Amazonian Gecko Genus Gonatodes (Sphaerodactylidae, Squamata)}

Tony Gamble Conservation Biology Graduate Program, Bell Museum of Natural History, University of Minnesota, St. Paul, MN Andrew M. Simons

Bell Museum of Natural History, Department of Fisheries, Wildlife, and Conservation Biology, University of Minnesota, St. Paul, MN

Guarino R. Colli

Coleção Herpetológica da UnB, Departamento de Zoologia, Universidade de Brasília, Brasília, Distrito Federal, Brazil

Laurie J. Vitt

Sam Noble Oklahoma Museum of Natural History, Department of Zoology, University of Oklahoma, Norman, OK 


\section{Abstract}

The genus Gonatodes is a monophyletic group of small-bodied, diurnal geckos distributed across northern South America, Central America, and the Caribbean. We used fragments of three nuclear genes (RAG2, ACM4, and cmos) and one mitochondrial gene (16S) to estimate phylogenetic relationships among Amazonian species of Gonatodes. We used Penalized Likelihood to estimate timing of diversification in the genus. Most cladogenesis occurred in the Oligocene and early Miocene and coincided with a burst of diversification in other South American animal groups including mollusks, birds, and mammals. The Oligocene and early Miocene were periods dominated by dramatic climate change and Andean orogeny and we suggest that these factors drove the burst of cladogenesis in Gonatodes geckos as well as other taxa. A common pattern in Amazonian taxa is a biogeographic split between the eastern and western Amazon basin. We observed two clades with this spatial distribution, although large differences in timing of divergence between the east-west taxon pairs indicate that these divergences were not the result of a common vicariant event.

\section{Keywords}

Amazon, Partitioned Bayesian analysis, Penalized Likelihood, South America, Sphaerodactylidae

\section{Introduction}

Numerous explanations have been offered for the high levels of biological diversity found in tropical rainforests (Moritz et al., 2000). The refuge model ( $\underline{\text { Haffer, 1969) }}$ is perhaps the most discussed and most controversial model of diversification (Endler, 1982, Bush and Oliveira, 2006). The refuge model states that climate change has caused forests to contract to refugia with intervening non-forested habitat restricting gene flow among forest-dwelling species. Speciation in this scenario is allopatric. Although the refuge model was developed based on Pleistocene temperature fluctuations, climatic variation throughout the Cenozoic could also promote diversification (Haffer, 1997). While many of the details of the refuge model have been criticized, the generalization that global climatic fluctuations coincide with and even drive changes in tropical biodiversity, either increased rates of extinction or bursts of diversification, is still plausible even if the exact mechanisms of cladogenesis are unknown (Whinnett et al., 2005, Delsuc et al., 2004). Past efforts by biogeographers to support the refuge model have focused on spatial analyses to find common patterns in species' distributions.

Concordant spatial patterns among co-distributed taxa were seen as evidence of a common process affecting their distribution. In a similar manner, simultaneous cladogenesis across multiple taxa coinciding with periods of climate change would support the idea that periods of climatic fluctuations influence rates of diversification.

Advances in molecular phylogenetics have made it possible to estimate divergence dates from molecular genetic data with increasing levels of accuracy (Welch and Bromham, 2005). Molecular dating of phylogenies complements paleontological and geological data in studying the relationship between biotic diversification and climatic variation (Benner et al., 2002). These new dating techniques have shown that diversification often coincides with periods of climatic change in taxa as diverse as salamanders (Zhang et al., 2006), pelagic protists (Darling et al., 2004), birds (Tavares et al., 2006), and mammals (Mercer and Roth, 2003). Examples among South American mammals are particularly compelling as sloths, armadillos, didelphid marsupials, and caviomorph rodents all diversified around the Oligocene-Miocene boundary, a period dominated by dramatic climatic change and Andean orogeny (Delsuc et al., 2004, Steiner et al., 2005, Poux et al., 2006). The environmental changes driving this burst of diversification in mammals would likely have left their mark on other organisms as well.

Here we examine the timing of diversification in a clade of South American gecko lizards. The genus Gonatodes is a monophyletic group of small-bodied, diurnal geckos distributed across northern South America, Central America, and the Caribbean (Vanzolini, 1968, Kluge, 1995). Extant members of the genus are 
abundant in forested areas and are important components of Amazonian lizard communities (Rivero-Blanco, 1979 , Vitt et al., 2000). The Sphaerodactylini, the clade containing Gonatodes and closely related genera, have been a part of the South American fauna since the Africa-South America split approximately $95 \mathrm{Ma}$ (Gamble et al., 2007), and constituent genera provide an excellent model to examine Neotropical diversification. Our objectives are to: (1) use multiple molecular genetic loci to estimate phylogenetic relationships among Amazonian species of Gonatodes; (2) use a relaxed molecular clock to estimate timing of cladogenesis in Gonatodes; and (3) interpret the timing of Gonatodes diversification in light of prior knowledge regarding Amazonian paleo-biogeography, specifically periods of climate change and Andean uplift.

\section{Materials and methods}

\subsection{Taxon sampling}

We sampled 11 of the 20 described Gonatodes species and one undescribed species from Guyana. Our sampling included all of the Amazonian Gonatodes except G. tapajonicus and G. alexandermendesi, both of which are poorly known and found only at or near their type localities. The genus Lepidoblepharis has been shown to be the sister-group to Gonatodes (Gamble et al., 2007) and three species of Lepidoblepharis were used as outgroups. Four species of Sphaerodactylus were also included as outgroups, as there are amberpreserved Sphaerodactylus that can be used as a calibration point for phylogenetic dating. Finally, the Moroccan gecko Saurodactylus brossetti was used to root the tree. Saurodactylus is the sister taxon to the five genera of New World sphaerodactylid geckos (Gamble et al., 2007). Locality data, museum catalog numbers or field numbers, and GenBank accession numbers for sampled taxa are listed in Table 1.

Table 1. Details of material examined

\begin{tabular}{|l|l|l|l|l|l|l|}
\hline Species & Specimen ID & Locality & $\begin{array}{l}\text { GenBank } \\
\text { accession } \\
\text { numbers }\end{array}$ & & & \\
\hline & & & 16S & RAG 2 & c-mos & ACM4 \\
\hline Saurodactylus brosseti & TG 00082 & Morocco & EF564006 & EF534970 & EF534928 & EF534885 \\
\hline $\begin{array}{l}\text { Sphaerodactylus } \\
\text { notatus }\end{array}$ & $\begin{array}{l}\text { FLMNH } \\
132440\end{array}$ & Florida, USA & X86061 & EF564093 & EF564067 & EF564041 \\
\hline $\begin{array}{l}\text { Sphaerodactylus } \\
\text { nigropunctatus }\end{array}$ & $\begin{array}{l}\text { FLMNH } \\
144010\end{array}$ & Bahamas & X86051 & EF534953 & EF534911 & EF534868 \\
\hline $\begin{array}{l}\text { Sphaerodactylus } \\
\text { elegans }\end{array}$ & YPM 14795 & Florida, USA & X86048 & EF534954 & EF534912 & EF534869 \\
\hline Sphaerodactylus torrei & JB 34 & Cuba & X86052 & EF534955 & EF534913 & EF534870 \\
\hline Lepidoblepharis sp. & KU 218367 & Manabi, Ecuador & EF564008 & EF534956 & EF534914 & EF534871 \\
\hline $\begin{array}{l}\text { Lepidoblepharis festae } \\
\text { LSUMZ } \\
12704\end{array}$ & $\begin{array}{l}\text { Sucumbios, } \\
\text { Ecuador }\end{array}$ & EF564007 & EF564094 & EF564068 & EF564042 \\
\hline $\begin{array}{l}\text { Lepidoblepharis } \\
\text { xanthostigma }\end{array}$ & $\begin{array}{l}\text { MVZ } \\
171438\end{array}$ & Limon, Costa Rica & EF564009 & EF534957 & EF534915 & EF534872 \\
\hline $\begin{array}{l}\text { Lepidoblepharis } \\
\text { xanthostigma }\end{array}$ & $\begin{array}{l}\text { USNM } \\
59912\end{array}$ & Panama & EF564010 & EF564095 & EF564069 & EF564043 \\
\hline Gonatodes albogularis & KDQ 512 & Costa Rica & EF564023 & EF564105 & EF564079 & EF564053 \\
\hline Gonatodes albogularis & KU 289808 & El Salvador & EF564021 & EF534965 & EF534923 & EF534880 \\
\hline Gonatodes albogularis & MF 10276 & Costa Rica & EF564022 & EF564104 & EF564078 & EF564052 \\
\hline $\begin{array}{l}\text { Gonatodes albogularis } \\
\text { MUHNES } \\
1493\end{array}$ & El Salvador & EF564024 & EF564106 & EF564080 & EF564054 \\
\hline $\begin{array}{l}\text { Gonatodes albogularis } \\
\text { MVZ } \\
204073\end{array}$ & Limon, Costa Rica & EF564020 & EF564103 & EF564077 & EF564051 \\
\hline $\begin{array}{l}\text { Gonatodes albogularis } \\
\text { USNM } \\
319194\end{array}$ & Panama & EF564019 & EF564102 & EF564076 & EF564050 \\
\hline
\end{tabular}




\begin{tabular}{|c|c|c|c|c|c|c|}
\hline Gonatodes annularis & ROM 22961 & $\begin{array}{l}\text { Northwest, } \\
\text { Guyana }\end{array}$ & EF564036 & EF534961 & EF534919 & EF534876 \\
\hline Gonatodes annularis & $\begin{array}{l}\text { No ID } \\
\text { number }\end{array}$ & French Guiana & EF564037 & EF564115 & EF564089 & EF564063 \\
\hline $\begin{array}{l}\text { Gonatodes } \\
\text { caudiscutatus }\end{array}$ & KU 218359 & Limon, Ecuador & EF564011 & EF534962 & EF534920 & EF534877 \\
\hline Gonatodes ceciliae & TG 00039 & Trinidad & EF564035 & EF564114 & EF564088 & EF564062 \\
\hline Gonatodes concinnatus & $\begin{array}{l}\text { LSUMZ } \\
12688 \\
\end{array}$ & $\begin{array}{l}\text { Sucumbios, } \\
\text { Ecuador }\end{array}$ & EF564012 & EF564096 & EF564070 & EF564044 \\
\hline Gonatodes concinnatus & MF 19449 & $\begin{array}{l}\text { Orellana, } \\
\text { Ecuador }\end{array}$ & EF564013 & EF564097 & EF564071 & EF564045 \\
\hline Gonatodes daudinii & JB 38 & $\begin{array}{l}\text { Union, St. } \\
\text { Vincent and } \\
\text { Grenadines }\end{array}$ & EF564034 & EF534960 & EF534918 & EF534875 \\
\hline Gonatodes eladioi & $\begin{array}{l}\text { CHUNB } \\
40097\end{array}$ & Pará, Brazil & EF564025 & EF564107 & EF564081 & EF564055 \\
\hline Gonatodes hasemani & GRC 6761 & Rondônia, Brazil & EF564039 & EF564117 & EF564091 & EF564065 \\
\hline Gonatodes hasemani & $\begin{array}{l}\text { LSUMZ } \\
13618 \\
\end{array}$ & Acre, Brazil & EF564016 & EF564099 & EF564073 & EF564047 \\
\hline Gonatodes hasemani & $\begin{array}{l}\text { LSUMZ } \\
14058\end{array}$ & Amazonas, Brazil & EF564017 & EF564100 & EF564074 & EF564048 \\
\hline Gonatodes hasemani & $\begin{array}{l}\text { LSUMZ } \\
17777 \\
\end{array}$ & Rondônia, Brazil & EF564018 & EF564101 & EF564075 & EF564049 \\
\hline Gonatodes hasemani & $\begin{array}{l}\text { UNIBAN } \\
1649\end{array}$ & Rondônia, Brazil & EF564015 & EF534963 & EF534921 & EF534878 \\
\hline Gonatodes humeralis & $\begin{array}{l}\text { CHUNB } \\
31161\end{array}$ & Pará, Brazil & EF564040 & EF564118 & EF564092 & EF564066 \\
\hline Gonatodes humeralis & $\begin{array}{l}\text { LSUMZ } \\
12639 \\
\end{array}$ & $\begin{array}{l}\text { Sucumbios, } \\
\text { Ecuador }\end{array}$ & EF564030 & EF564110 & EF564084 & EF564058 \\
\hline Gonatodes humeralis & $\begin{array}{l}\text { LSUMZ } \\
14193\end{array}$ & Pará, Brazil & EF564031 & EF564111 & EF564085 & EF564059 \\
\hline Gonatodes humeralis & $\begin{array}{l}\text { LSUMZ } \\
14194 \\
\end{array}$ & Pará, Brazil & EF564029 & EF564109 & EF564083 & EF564057 \\
\hline Gonatodes humeralis & MF 19492 & Ecuador & EF564027 & EF534964 & EF534922 & EF534879 \\
\hline Gonatodes humeralis & ROM 20520 & Guyana & EF564038 & EF564116 & EF564090 & EF564064 \\
\hline Gonatodes humeralis & WED 57873 & Peru & EF564028 & EF564108 & EF564082 & EF564056 \\
\hline Gonatodes ocellatus & TG 00038 & Tobago & EF564014 & EF564098 & EF564072 & EF564046 \\
\hline Gonatodes sp. & BPN 1303 & $\begin{array}{l}\text { Imbaimadai, } \\
\text { Guyana }\end{array}$ & EF564026 & EF534966 & EF534924 & EF534881 \\
\hline Gonatodes vittatus & MF 382 & Trinidad & EF564033 & EF564113 & EF564087 & EF564061 \\
\hline Gonatodes vittatus & TG 00040 & Trinidad & EF564032 & EF564112 & EF564086 & EF564060 \\
\hline
\end{tabular}

Museum abbreviations follow Leviton et al. (1985) except as follows: TG, Tony Gamble; JB, Jon Boone; BPN, Brice Noonan; GRC, Guarino R. Colli; KDQ, Kevin de Queiroz; MF, Mike Forstner; UNIBAN, Universidade Bandeirantes de São Paulo; WED, William E. Duellman.

\subsection{DNA sequencing and alignment}

Genomic DNA was extracted from liver, muscle, or tail clips using the DNeasy Blood \& Tissue kit (Qiagen). PCR was used to amplify a fragment of the mitochondrial ribosomal gene 165 and portions of three nuclear proteincoding genes, recombination activating gene 2 (RAG2), oocyte maturation factor MOS (c-mos), and acetylcholinergic receptor M4 (ACM4 or CHRM4). Primers used for PCR and sequencing are listed in Table 2. PCR products were purified using Exonuclease I and Shrimp Alkaline Phosphatase (Hanke and Wink, 1994). 
Sequencing was performed using Big Dye (Perkin-Elmer) terminator cycle sequencing with an $\mathrm{ABI} 3730 \mathrm{xl}$ at the Advanced Genetic Analysis Center, University of Minnesota. Mitochondrial 165 sequences for several Sphaerodactylus species were downloaded from GenBank (Table 1).

Table 2. Primers used for PCR and sequencing

\begin{tabular}{|l|l|l|}
\hline Primer name & Primer sequence $\left(5^{\prime}-3^{\prime}\right)$ & Source \\
\hline 165 & & \\
\hline $16 S-F$ & CTAACCGTGCAAAGGTAGCGTAATCAC & This paper \\
\hline $16 \mathrm{~d}$ & CTCCGGTCTGAACTCAGATCACGTAG & Reeder (1995) \\
\hline RAG 2 & & \\
\hline EM1-F & TGGAACAGAGTGATYGACTGCAT & Gamble et al. (2007) \\
\hline EM1-R & ATTTCCCATATCAYTCCCAAACC & Gamble et al. (2007) \\
\hline PY1-F & CCCTGAGTTTGGATGCTGTACTT & Gamble et al. (2007) \\
\hline PY1-R & AACTGCCTRTTGTCCCCTGGTAT & Gamble et al. (2007) \\
\hline C-mos & & \\
\hline G73 & GCGGTAAAGCAGGTGAAGAAA & Saint et al. (1998) \\
\hline G74 & TGAGCATCCAAAGTCTCCAATC & Saint et al. (1998) \\
\hline FU-F & TTTGGTTCKGTCTACAAGGCTAC & Gamble et al. (2007) \\
\hline FU-R & AGGGAACATCCAAAGTCTCCAAT & Gamble et al. (2007) \\
\hline ACM4 & & \\
\hline tg-F & CAAGCCTGAGAGCAARAAGG & Gamble et al. (2007) \\
\hline tg-R & ACYTGACTCCTGGCAATGCT & Gamble et al. (2007) \\
\hline int-F & TTTYCTGAAGAGCCCTCTGGTC & This paper \\
\hline int-R & CAAATTTCCTGGCAACATTRGC & This paper \\
\hline
\end{tabular}

Sequences were edited and assembled with Sequencher 4.2 (Gene Codes Corporation) and aligned using TCoffee (Notredame et al., 2000). Sequences from protein-coding genes were translated to amino acids using MacClade 4.08 (Maddison and Maddison, 1992) to confirm alignment and gap placement. Secondary structure of aligned $16 \mathrm{~S}$ sequences was calculated using Vienna RNA secondary structure prediction software ( $\underline{\text { Hofacker et }}$ al., 2002, http://www.rna.tbi.univie.ac.at/cgi-bin/alifold.cgi) with Gonatodes albogularis (MF 10276) as the model. Some regions of the 165 gene were excluded because of difficulty in assessing homology.

\subsection{Phylogenetic reconstruction}

We conducted maximum parsimony analysis in PAUP $* 4.0$ b10 (Swofford, 2001) using heuristic search, starting with stepwise addition trees with 100 random addition replicates, and tree-bisection-reconnection branch swapping. Multistate characters were treated as polymorphism and gaps as missing data. Relative support for nodes was evaluated using 1000 bootstrap replicates (Felsenstein, 1985).

Bayesian phylogenetic analyses were conducted using MrBayes 3.1.2 (Huelsenbeck and Ronquist, 2001). Analyses began with a random starting tree, were run for 2,000,000 generations, and sampled every 100 generations with default search parameters. Burn in was determined using the program Tracer 1.3 (A. Rambaut and A. Drummond, Univ. Oxford, UK; http://www.evolve.zoo.ox.ac.uk/beast). Post burn-in samples were used to estimate the posterior probability values, branch lengths, and topology. The Akaike Information Criterion (AIC) was used to select the best-fit model of nucleotide substitution for each data partition, as implemented in MrModeltest 2.2 (Nylander, 2004).

Datasets were combined for all phylogenetic analyses and Bayes factors were used to determine the most appropriate partitioning scheme for the Bayesian analysis to ensure that the model was not over- or underparameterized (Nylander et al., 2004, Brandley et al., 2005). Bayes factors were computed as the difference between the harmonic mean likelihoods of the more complex partitioning strategy $\left(T_{0}\right)$ and the simpler 
partitioning strategy $\left(T_{1}\right)$ (Nylander et al., 2004, Brandley et al., 2005). We considered hypotheses with 2 In Bayes factors with a value $>10$ as very strongly supported (Kass and Raftery, 1995). Five different data partitioning strategies were examined, P1-all data combined (1 partition); P2-data partitioned by nuclear or mitochondrial genome ( 2 partitions); P3 - data partitioned by gene (4 partitions); P4-data partitioned by codon for each gene individually plus 165 (10 partitions); and P5-data partitioned by codon for each gene individually plus 165 partitioned by stem or loop structure (11 partitions). A final Bayesian analysis was run, using the best-fit partitioning strategy, for 10,000,000 generations with other parameters as described above to ensure convergence.

\subsection{Divergence date estimates}

We tested the best-fit partitioned Bayes topology for departure from a molecular clock using the likelihood ratio test as implemented in PAUP*. Absolute ages of nodes can be estimated directly if a phylogeny is clock-like but non-clock-like phylogenies require a rate-smoothing approach to dating nodes. We also estimated divergence times using Penalized Likelihood (PL) (Sanderson, 1997) with TN algorithm as implemented in the program r8s

(Sanderson, 2003). We used the cross-validation method in r8s to determine the optimal level of rate-smoothing of the PL analyses with smoothing parameters varying from 1 to $1 \times 10^{9}$. To estimate $95 \%$ confidence intervals of divergence time estimates we constructed 100 bootstrap datasets of the combined data using the seqboot module in PHYLIP 3.6 (Felsenstein, 1993). Branch lengths were estimated from each bootstrapped dataset on the best-fit, partitioned Bayesian phylogeny using PAUP* 4.0b10 (Swofford, 2001). We performed PL on each of these datasets and summarized the node statistics using the profile command in $\mathrm{r} 8 \mathrm{~s}$. The amber preserved Sphaerodactylus sp. (Kluge, 1995) and S. dommeli (Böhme, 1984) were used to fix the node containing S. elegans and its sister clade to $23 \mathrm{Ma}$ (Grimaldi, 1995) in the r8s analysis. A fixed date was used for this calibration as r8s analyses require at least one node have an upper and lower bound. We pruned taxa from the PL analysis in instances where more than one individual per species had been included. Pruning was necessary since r8s requires non-zero branch lengths leading to all taxa and some of the branches leading to redundant terminal taxa had zero branch lengths.

\section{Results}

\subsection{Phylogeny}

We excluded 83 sites from the aligned 165 dataset due to gaps and difficulties assessing homology (an annotated data matrix is available from the corresponding author). Sequence alignment was unambiguous for protein-coding genes, but there were insertion/deletion (indel) events in c-mos and ACM4. The 12 bp deletion in c-mos at position 231 in G. annularis, G. hasemani, and Gonatodes sp. is a synapomorphy for that clade. Similarly, a $3 \mathrm{bp}$ insertion at position 150 of $A C M 4$ is a synapomorphy for the clade containing $G$. albogularis and G. vittatus.

Parsimony analysis recovered 2608 most parsimonious trees (tree length $=988$, Consistency Index $=0.617$, Retention Index $=0.807$ ). A $50 \%$ majority-rule consensus of the most-parsimonious trees produced a topology that was congruent with the partitioned Bayesian topology. The best-fit partitioning strategy for the Bayesian analysis, as determined by Bayes factors, was the most parameter-rich model that included 11 partitions, data partitioned by codon for each gene individually, plus 165 partitioned by stem and loop structure. Sequence length and model parameters for each partition are listed in Table 3. Bayesian tree topology and branch support values are shown in Fig. 1. We recovered a sister-group relationship between Lepidoblepharis and Gonatodes. Within Gonatodes, most clades received posterior probabilities greater than 0.95 , while only clades with Bayesian posterior probabilities of 1.00 received significant parsimony bootstrap support. 
Table 3. Estimated models of sequence evolution and total number of characters for each data partition used in the Bayesian phylogenetic analyses

\begin{tabular}{|c|c|c|}
\hline Partition & Model & \# of characters in partition \\
\hline All data & $\mathrm{GTR}+\mathrm{I}+\Gamma$ & 1584 \\
\hline nDNA & GTR+Г & 1203 \\
\hline RAG 2 & $\mathrm{HKY}+\Gamma$ & 365 \\
\hline$c-m o s$ & $\mathrm{GTR}+\Gamma$ & 384 \\
\hline ACM4 & $\mathrm{HKY}+\Gamma$ & 453 \\
\hline $16 S$ & $\mathrm{GTR}+\mathrm{I}+\Gamma$ & 475 \\
\hline RAG 2 1st codon & GTR+r & 121 \\
\hline RAG 2 2nd codon & $\mathrm{HKY}+\mathrm{I}$ & 122 \\
\hline RAG 2 3rd codon & $\mathrm{HKY}+\Gamma$ & 122 \\
\hline$c-m o s$ 1st codon & $\mathrm{HKY}+\mathrm{I}$ & 128 \\
\hline$c-m o s 2 n d$ codon & $\mathrm{HKY}+\mathrm{I}$ & 128 \\
\hline c-mos 3rd codon & GTR+I & 127 \\
\hline ACM4 1st codon & $\mathrm{HKY}+\mathrm{I}$ & 151 \\
\hline ACM4 2nd codon & $\mathrm{HKY}+\mathrm{I}$ & 151 \\
\hline ACM4 3rd codon & SYM+I & 151 \\
\hline $16 S$ stems & SYM+r & 167 \\
\hline 165 loops & $\mathrm{GTR}+\mathrm{I}+\Gamma$ & 308 \\
\hline
\end{tabular}

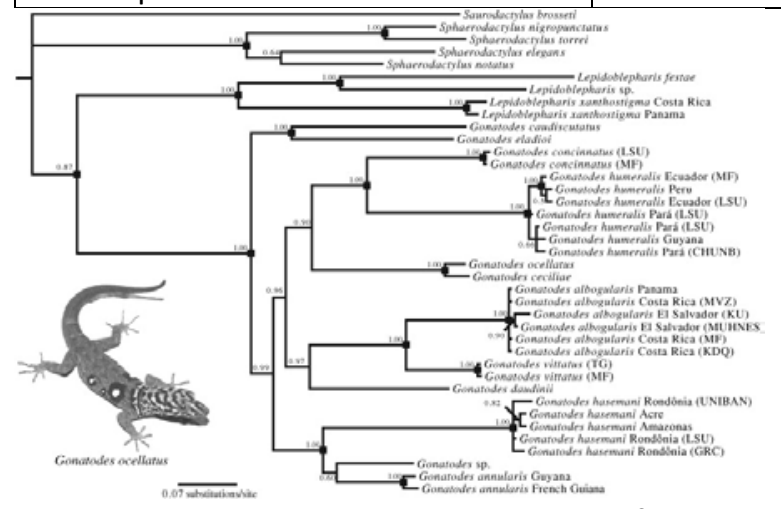

Fig. 1. Partitioned Bayesian phylogeny of Gonatodes geckos and outgroups. Numbers above nodes indicate Bayesian posterior probabilities while black squares indicate nodes with parsimony bootstrap support $>70$.

\subsection{Divergence date estimates}

The likelihood ratio test rejected the molecular clock for this data $(-2 \ln \Lambda=59.25, \mathrm{df}=37, P=0.012)$. Because the phylogeny departed from a molecular clock, we relied on the PL method with TN algorithm to estimate dates of divergence. Cross-validation analyses indicated several appropriate smoothing parameters and we used a smoothing parameter of 100,000 for these data.

Dates were largely concordant with a recent analysis of the entire Sphaerodactylidae derived from a nonparametric-rate-smoothing analysis (Gamble et al., 2007), which used as calibration points the amber Sphaerodactylus and fossil Euleptes as a minimum age constraints and two fixed-age constraints related to vicariant events in central Asia for the gecko genus Teratoscincus (Gamble et al., 2007). Gamble et al. (2007) for example, recovered divergence dates for the Lepidoblepharis/Gonatodes split at $68 \mathrm{Ma}$, the divergence of $G$. caudiscutatus from the remaining Gonatodes at $34 \mathrm{Ma}$, and $\mathrm{G}$. daudinii from G. albogularis at $26 \mathrm{Ma}$. Our analyses recovered dates for those same divergences at 64, 35, and $23 \mathrm{Ma}$, respectively. Most cladogenesis in Gonatodes occurred in the Oligocene and early Miocene (Table 4 and Fig. 2).

Table 4. Estimated ages (in millions of years) and width of the corresponding $95 \%$ confidence intervals for all nodes, obtained using Penalized Likelihood

\begin{tabular}{|l|c|c|}
\hline Node & Age & $\mathrm{Cl}$ \\
\hline
\end{tabular}




\begin{tabular}{|l|l|l|}
\hline A & 69.7 & 12.3 \\
\hline B & 64.0 & 11.7 \\
\hline C & 42.0 & 8.4 \\
\hline D & 35.0 & 6.8 \\
\hline E & 30.0 & 4.8 \\
\hline F & 32.0 & 6.4 \\
\hline G & 30.0 & 5.6 \\
\hline H & 28.0 & 5.8 \\
\hline I & 29.0 & 6.1 \\
\hline J & 26.0 & 5.6 \\
\hline K & 23.0 & 0.0 \\
\hline L & 27.0 & 4.4 \\
\hline M & 23.0 & 4.7 \\
\hline N & 18.0 & 3.9 \\
\hline O & 21.0 & 4.3 \\
\hline P & 13.0 & 3.0 \\
\hline Q & 10.0 & 2.5 \\
\hline R & 3.8 & 0.4 \\
\hline S & 2.7 & 1.1 \\
\hline T & 1.9 & 0.8 \\
\hline
\end{tabular}

Node labels are shown in Fig. 2.

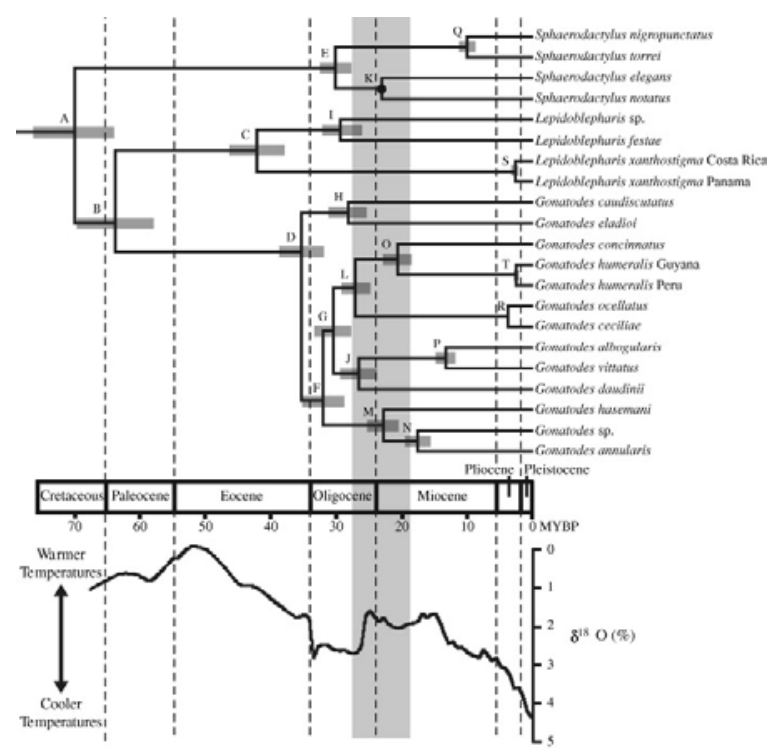

Fig. 2. Chronogram of the partitioned Bayesian phylogeny of Gonatodes geckos and outgroups generated using Penalized Likelihood. Approximate divergence dates are indicated along the $x$-axis. Gray bars indicate the $95 \%$ confidence intervals calculated from the bootstrap analysis. Actual dates and confidence intervals are listed in Table 4. The black circle represents the fixed-age node calibrated using the amber-preserved Sphaerodactylus. Vertical gray bar indicates the timing of central Andean uplift approximately 19-27 Ma (Marshall and Sempere, 1993). The black curve represents oxygen isotope data taken from sea sediments (from Zachos et al., 2001, reprinted with permission from AAAS), which can be interpreted as a proxy for ocean temperature where higher $\delta^{18} \mathrm{O} \%$ values correlate with lower ocean temperatures. 


\section{Discussion}

\subsection{Phylogeny}

Our results provide the first comprehensive analysis of Gonatodes relationships. Within Gonatodes, we corroborate the evolutionary relationships of several previously hypothesized taxonomic groups. These include clustering of $G$. albogularis $+G$. vittatus as well as the $G$. ceciliae $+G$. ocellatus grouping based on osteological data (Rivero-Blanco, 1979).

This is the first published phylogeny for a widespread and common lizard genus such as Gonatodes. Behavioral and vision studies (Marcellini, 1977, Ellingson et al., 1995) have exploited the sexual dimorphism and the colorful nature of male Gonatodes, and several species have been the focus of ecological research (Sexton and Turner, 1972, Duellman, 1978, Vitt et al., 1997, Vitt et al., 2000, Fuenmayor and Molina, 2004, Rojas-Runjiac and Fuenmayor, 2006, Fuenmayor et al., 2006). We hope that our analyses provide a scaffold for future research on the evolutionary biology of this fascinating group of lizards.

\subsection{Divergence date estimates and diversification}

Lepidoblepharis and Gonatodes diverged in the early Paleocene although the contemporary diversity in Gonatodes has its origins in the late Eocene and Oligocene, a period characterized by significant global cooling and drying (Flynn and Wyss, 1998). The late Eocene and Oligocene saw a dramatic increase in the size of Antarctic ice sheets, lower sea levels, and changes in ocean currents as South America, Antarctica, and Australia separated, creating a continuous ocean current around Antarctica (Zachos et al., 2001). All of these changes initiated considerable transformations in terrestrial ecosystems. Three cladogenic events in Gonatodes coincided with this period of cooling, (1) divergence of $G$. caudiscutatus $+G$. eladioi from the remaining Gonatodes; (2) divergence of the clade comprised of $G$. hasemani $+G$. annularis + Gonatodes sp.; and (3) the split between the $G$. concinnatus $+G$. humeralis $+G$. ocellatus $+G$. ceciliae clade and the clade composed of G. albogularis $+G$. vittatus $+G$. daudinii. Three of the four clades resulting from these three divergences contain extant Amazonian species. The fourth clade, containing G. albogularis $+G$. vittatus $+G$. daudinii, consists of species restricted to northern South America, Central America, and the Antilles.

The Oligocene-Miocene boundary contains most of the remaining cladogenesis in our analyses. From 19 to 27 Ma South America was dominated by the uplift of the Andes (Marshall and Sempere, 1993, GregoryWodzicki, 2000). Vicariance due to Andean uplift is the most obvious manifestation of this impact. Our dataset contains two taxon pairs found on opposite sides of the Andes, G. caudiscutatus found west of the Andes, and G. eladioi from the Amazon basin east of the Andes; and the two Lepidoblepharis species from Ecuador, with Lepidoblepharis sp. found west of the Andes and L. festae from east of the Andes. Both of these splits occurred during or slightly prior to this period of Andean uplift. Oligocene-Miocene orogeny in western South America also significantly influenced climate on the continent by forming the largest atmospheric circulation barrier in the southern hemisphere (Lenters and Cook, 1995). This created a rain shadow on the western side of South America (Marshall and Sempere, 1993) and changed river drainage patterns (Wesselingh and Salo, 2006). It is likely that these indirect environmental effects influenced the Oligocene-early Miocene cladogenic events in our phylogeny.

A recurring theme in Amazonian biogeography is a biogeographic split between the eastern and western Amazon basin. This east-west pattern has been observed in many biogeographic studies based on species distributions of butterflies (Hall and Harvey, 2002), lizards (Avila-Pires, 1995), frogs (Ron, 2000), birds (Bates et al., 1998), and primates (da Silva and Oren, 1996). A similar pattern has also been observed in molecular

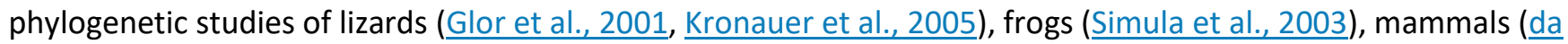
Silva and Patton, 1993), and birds (Eberhard and Bermingham, 2005). Glor et al. (2001) found that east-west 
taxon pairs of Anolis lizards exhibited temporal discordance, as determined by the level of mitochondrial DNA sequence divergence, indicating that congruent biogeographic patterns were not the result of common vicariant events. We also observed a similar pattern of temporal discordance with east-west taxon pairs. The divergence between the western Amazonian Gonatodes hasemani and the eastern Amazonian clade containing G. annularis + Gonatodes sp. occurred approximately $23 \mathrm{Ma}$, while the timing of divergence between eastern and western Amazonian $G$. humeralis occurred much more recently, approximately 1.9 Ma. These examples highlight the importance of including a temporal aspect to biogeographic studies. Examining solely spatial patterns, while informative, could be misleading where taxon pairs share broadly concordant distributions but diverged at different times.

The majority of Gonatodes diversification in the Oligocene and early Miocene coincides with the timing of diversification in several other South American animal groups. Other taxa with bursts of diversification during this period include mollusks (Wesselingh and Salo, 2006), leptodactylid frogs (Heyer and Maxson, 1982), didelphid marsupials (Steiner et al., 2005), macaws and conures (Tavares et al., 2006), sloths and armadillos (Delsuc et al., 2004), and caviomorph rodents (Poux et al., 2006). Possible causes of diversification across such a wide range of taxa during the late Oligocene and early Miocene include forest fragmentation ( 1969, Haffer, 1997), changing river drainage patterns and oceanic incursions (Flynn and Wyss, 1998, Wesselingh and Salo, 2006), or niche diversification (Schluter, 2000). Regardless of the precise mechanisms, the Oligocene and early Miocene is a vitally important period in the development of South America's biological diversity. Tertiary divergences in these and other taxa also show that Pleistocene climate change (sensu $\underline{\text { Haffer, 1969) }}$ seems to have had little influence on major patterns of Amazonian diversification.

Our results confirm that climate change and orogeny during the Tertiary played an important role in the diversification of the South American fauna, including Gonatodes geckos. Future work that includes greater taxonomic sampling within Gonatodes as well as other genera of South American sphaerodactylid gecko genera (e.g. Coleodactylus, Lepidoblepharis, and Pseudogonatodes) would provide an additional test of the Tertiary diversification hypothesis.

\section{Acknowledgments}

We thank F. Keith Barker, Aaron M. Bauer, Jacob J.D. Egge, Sharon Jansa, and two anonymous reviewers for assistance with data analyses and comments on the manuscript. Dave Kizirian provided useful copies of the relevant literature. Ashley Schultz provided help in the lab. Many thanks to Daniel Mesquita, Fernanda Werneck, and Helga Wiederhecker for assistance with permits. Aaron Bauer, Jon Boone, Rob Brumfield and LSU Museum of Natural Science Collection of Genetic Resources, Mike Forstner, Gilson Rivas Fuenmayor, Tom Heagy, Kenny Krysko, Jim McGuire, Bob Murphy, Brice Noonan, John Simmons, Jens Vindum, Greg Watkins-Colwell, Addison Wynn, and Hussam Zaher provided tissues from material in their care. Support for this research was provided by a Dayton/Wilkie Fund, Bell Museum of Natural History grant to TG; and NSF grant "Phylogeny and Evolution of the Geckos of the World" (DEB 0515909) to A.M. Bauer and T.R. Jackman with subaward to AMS. Fieldwork conducted by Laurie J. Vitt and Jan. P. Caldwell was supported by NSF Grants DEB 9200779, DEB 9505518, and

DEB 0415430. Fieldwork conducted by Guarino R. Colli was covered by IBAMA permit 027/2003-CGFAU/LIC and supported by Programa Nacional de Diversidade Biológica PROBIO/MMA, project "Paisagens e biodiversidade: uma perspectiva integrada para o inventário e conservação da Serra do Cachimbo", and by a research fellowship (\#302343/88-1) from Conselho Nacional de Desenvolvimento Científico e Tecnológico (CNPq).

\section{References}

Avila-Pires, 1995 T.C.S. Avila-Pires Lizards of Brazilian Amazonia (Reptilia, Squamata) Zool. Verh., 299 (1995), pp. 1-706 
Bates et al., 1998 J.M. Bates, S.J. Hackett, J. Cracraft Area-relationships in the Neotropical lowlands: an hypothesis based on raw distributions of Passerine birds J. Biogeogr., 25 (1998), pp. 783-793

Böhme, 1984 W. Böhme Erstfund eines fossilen Kugelfingergeckos (Sauria, Gekkonidae, Sphaerodactylinae) aus Dominikanischem Bernstein (Oligozan von Hispaniola, Antillen) Salamandra, 20 (1984), pp. 212220

Brandley et al., 2005 M.C. Brandley, A. Schmitz, T.W. Reeder Partitioned Bayesian analyses, partition choice, and the phylogenetic relationships of scincid lizards Syst. Biol., 54 (2005), pp. 373-390

Benner et al., 2002 S.A. Benner, M.D. Caraco, J.M. Thomson, E.A. Gaucher Planetary biology: paleontological, geological, and molecular histories of life Science, 296 (2002), pp. 864-868

Bush and Oliveira, 2006 M.B. Bush, P.E. Oliveira The rise and fall of the Refugial Hypothesis of Amazonian speciation: a paleoecological perspective Biota Neotropica 6 (2006)

Darling et al., 2004 K.F. Darling, M. Kucera, C.J. Pudsey, C.M. Wade Molecular evidence links cryptic diversification in polar planktonic protists to Quaternary climate dynamics Proc. Natl. Acad. Sci. USA, 101 (2004), pp. 7657-7662

da Silva and Oren, 1996 J.M.C. da Silva, D.C. Oren Application of parsimony analysis of endemicity in Amazonian biogeography, an example with primates Biol. J. Linn. Soc., 59 (1996), pp. 427-437

da Silva and Patton, 1993 M.N.F. da Silva, J.L. Patton Amazonian phylogeography: mtDNA sequence variation in arboreal echimyid rodents (Caviomorpha) Mol. Phylogenet. Evol., 2 (1993), pp. 243-255

Delsuc et al., 2004 F. Delsuc, S.F. Vizcai'no, E.J.P. Douzery Influence of Tertiary paleoenvironmental changes on the diversification of South American mammals: a relaxed molecular clock study within xenarthrans BMC Evol. Biol., 4 (2004), p. 11

Duellman, 1978 W.E. Duellman The biology of an equatorial herpetofauna in Amazonian Ecuador Misc. Publ. Mus. Nat. Hist. Univ. Kansas, 65 (1978), pp. 1-352

Eberhard and Bermingham, 2005 J.R. Eberhard, E. Bermingham Phylogeny and comparative biogeography of Pionopsitta parrots and Pteroglossus toucans Mol. Phylogenet. Evol., 36 (2005), pp. 288-304

Ellingson et al., 1995 J.M. Ellingson, L.J. Fleishman, E.R. Loew Visual pigments and spectral sensitivity of the diurnal gecko Gonatodes albogularis J. Comp. Physiol. A, 177 (1995), pp. 559-567

Endler, 1982 J.A. Endler Pleistocene forest refuges, fact or fancy G.T. Prance (Ed.), Biological Diversification in the Tropics, Columbia University Press, New York (1982), pp. 641-657

Felsenstein, $1985 \mathrm{~J}$. Felsenstein Confidence limits on phylogenies, an approach using the bootstrap Evolution, 39 (1985), pp. 783-791

Felsenstein, 1993 Felsenstein, J., 1993. PHYLIP (Phylogeny Inference Package), version 3.66. Department of Genetics, University of Washington.

Flynn and Wyss, 1998 J.J. Flynn, A.R. Wyss Recent advances in South American mammalian paleontology Trends Ecol. Evol., 13 (1998), pp. 449-454

Fuenmayor and Molina, 2004 G.R. Fuenmayor, C.R. Molina Field observations of the lizards Gonatodes annularis Boulenger, 1887 (Squamata, Gekkonidae) in Venezuela Gekko, 4 (2004), pp. 2-5

Fuenmayor et al., 2006 G.A.R. Fuenmayor, G.N. Ugueto, C.L. Barrio-Amorós, T.R. Barros Natural history and color variation in two species of Gonatodes (Gekkonidae) in Venezuela Herpetol. Rev., 37 (2006), pp. $412-416$

Gamble et al., 2007 T. Gamble, A.M. Bauer, E. Greenbaum, T.R. Jackman Evidence for Gondwanan vicariance in an ancient clade of gecko lizards J. Biogeogr. (2007)

Glor et al., 2001 R.E. Glor, L.J. Vitt, A. Larson A molecular phylogenetic analysis of diversification in Amazonian Anolis lizards Mol. Ecol., 10 (2001), pp. 2661-2668

Gregory-Wodzicki, 2000 K.M. Gregory-Wodzicki Andean paleoelevation estimates: a review and critique Geol. Soc. Am. Bull., 112 (2000), pp. 1091-1105

Grimaldi, 1995 D. Grimaldi On the age of Dominican amber K.B. Anderson, J.C. Crelling (Eds.), Amber, Resinite, and Fossil Resins, American Chemical Society, Washington, DC (1995), pp. 203-217

Haffer, 1969 J. Haffer Speciation in Amazonian forest birds Science, 165 (1969), pp. 131-137 
Haffer, $1997 \mathrm{~J}$. Haffer Alternative models of vertebrate speciation in Amazonia: an overview Biodiversity Conserv., 6 (1997), pp. 451-477

Hall and Harvey, 2002 J.P.W. Hall, D.J. Harvey The phylogeography of Amazonia revisited: new evidence from riodinid butterflies Evolution, 56 (2002), pp. 1489-1497

Hanke and Wink, 1994 M. Hanke, M. Wink Direct DNA sequencing of PCR amplified vector inserts following enzymatic degradation of primer and dNTPs BioTechniques, 17 (1994), pp. 858-860

Heyer and Maxson, 1982 W.R. Heyer, L.R. Maxson Distributions, relationships, and zoogeography of lowland frogs: the Leptodactylus complex in South America, with special reference to Amazonia G.T. Prance (Ed.), Biological Diversification in the Tropics, Columbia University Press, New York (1982), pp. $375-388$

Hofacker et al., 2002 I.L. Hofacker, M. Fekete, P.F. Stadler Secondary structure prediction for aligned RNA sequences J. Mol. Biol., 319 (2002), pp. 1059-1066

Huelsenbeck and Ronquist, 2001 J.P. Huelsenbeck, F. Ronquist MRBAYES, Bayesian inference of phylogeny Bioinformatics, 17 (2001), pp. 754-755

Kass and Raftery, 1995 R.E. Kass, A.E. Raftery Bayes factors J. Am. Stat. Assoc., 90 (1995), pp. 773-795

Kluge, 1995 A.G. Kluge Cladistic relationships of sphaerodactyl lizards Am. Mus. Novitat., 3139 (1995), pp. 1-23 Kronauer et al., 2005 D.J.C. Kronauer, P.J. Bergmann, J.M. Mercer, A.P. Russell A phylogeographically distinct and deep divergence in the widespread Neotropical turnip-tailed gecko, Thecadactylus rapicauda Mol. Phylogenet. Evol., 34 (2005), pp. 431-437

Lenters and Cook, 1995 J.D. Lenters, K.H. Cook Comments on "On the influence of the Andes on the general circulation of the Southern Hemisphere" J. Climate, 8 (1995), pp. 2113-2115

Leviton et al., 1985 A.E. Leviton, R.H. Gibbs, E. Heal, C.E. Dawson Standards in herpetology and ichthyology, part 1: standard symbolic codes for institutional resource collections in herpetology and ichthyology Copeia, 1985 (1985), pp. 802-832

Maddison and Maddison, 1992 Maddison, W.P., Maddison, D.R., 1992. MacClade, analysis of phylogeny and character evolution, version 3.0, Sinauer, Sunderland, MA.

Marcellini, 1977 D. Marcellini Acoustic and visual display behavior of gekkonid lizards Am. Zool., 17 (1977), pp. 251-260

Marshall and Sempere, 1993 L.G. Marshall, T. Sempere Evolution of the neotropical Cenozoic land mammal fauna in its geochronologic: stratigraphic, and tectonic context P. Goldblatt (Ed.), Biological relationships between Africa and South America, Yale University Press, New Haven, CT (1993), pp. 329392

Mercer and Roth, 2003 J.M. Mercer, V.L. Roth The effects of Cenozoic global change on squirrel phylogeny Science, 299 (2003), pp. 1568-1572

Moritz et al., 2000 C. Moritz, J.L. Patton, C.J. Schneider, T.B. Smith Diversification of rainforest faunas: an integrated molecular approach Ann. Rev. Ecol. Syst., 31 (2000), pp. 533-563

Notredame et al., 2000 C. Notredame, D.G. Higgins, J. Heringa T-Coffee, a novel method for fast and accurate multiple sequence alignment J. Mol. Biol., 302 (2000), pp. 205-217

Nylander, 2004 Nylander, J.A.A., 2004. MrModeltest v2. Program distributed by the author. Evolutionary Biology Centre, Uppsala University.

Nylander et al., 2004 J.A.A. Nylander, F. Ronquist, J.P. Huelsenbeck, J.L. Nieves-Aldrey Bayesian phylogenetic analysis of combined data Syst. Biol., 53 (2004), pp. 47-67

Poux et al., 2006 C. Poux, P. Chevret, D. Huchon, W.D. DeJong, E.J.P. Douzery Arrival and diversification of caviomorph rodents and platyrrhine primates in South America Syst. Biol., 55 (2006), pp. 228-244

Reeder, 1995 T.W. Reeder Phylogenetic relationships among phrynosomatid lizards as inferred from mitochondrial ribosomal DNA sequences: substitutional bias and the information content of transitions relative to transversions Mol. Phylogenet. Evol., 4 (1995), pp. 203-222

Rivero-Blanco, 1979 Rivero-Blanco, C., 1979. The neotropical lizard genus Gonatodes Fitzinger (Sauria, Sphaerodactylinae). Unpublished dissertation, Texas A\&M University. 
Rojas-Runjiac and Fuenmayor, 2006 F.J.M. Rojas-Runjiac, G.A.R. Fuenmayor Notes on the natural history and geographic distribution of Gonatodes petersi Donoso-Barros, 1967 (Sauria; Gekkonidae): an endemic and poorly known gecko of the Sierra de Perijá, Venezuela Gekko, 5 (2006), pp. 21-25

Ron, 2000 S.R. Ron Biogeographic area relationships of lowland neotropical rainforest based on raw distributions of vertebrate groups Biol. J. Linn. Soc., 71 (2000), pp. 379-402

Sanderson, 1997 M. Sanderson A nonparametric approach to estimating divergence times in the absence of rate constancy Mol. Biol. Evol., 14 (1997), pp. 1218-1231

Sanderson, $2003 \mathrm{M}$. Sanderson r8s: inferring absolute rates of molecular evolution and divergence times in the absence of a molecular clock Bioinformatics, 19 (2003), pp. 301-302

Schluter, 2000 D. Schluter The Ecology of Adaptive Radiation Oxford University Press, Oxford (2000)

Sexton and Turner, 1972 O.J. Sexton, O. Turner The reproductive cycle of a neotropical lizard Ecology, 52 (1972), pp. 159-164

Simula et al., 2003 R. Simula, R. Schulte, K. Summers Molecular systematics and phylogeography of Amazonian poison frogs of the genus Dendrobates Mol. Phylogenet. Evol., 26 (2003), pp. 452-475

Steiner et al., 2005 C. Steiner, M. Tilak, E.J.P. Douzery, F.M. Catzeflis New DNA data from a transthyretin nuclear intron suggest an Oligocene to Miocene diversification of living South America opossums (Marsupialia, Didelphidae) Mol. Phylogenet. Evol., 35 (2005), pp. 363-379

Swofford, 2001 D.L. Swofford PAUP*, Phylogenetic Analysis Using Parsimony (and Other Methods)4.0b10 Sinauer Associates Inc.,, Sunderland, MA (2001)

Tavares et al., 2006 E.S. Tavares, A.J. Baker, S.L. Pereira, C.Y. Miyaki Phylogenetic relationships and historical biogeography of neotropical parrots (Psittaciformes, Psittacidae, Arini) inferred from mitochondrial and nuclear DNA sequences Syst. Biol., 55 (2006), pp. 454-470

Vanzolini, 1968 P.E. Vanzolini Geography of the South American Gekkonidae (Sauria) Arq. Zool., 25 (1968), pp. 85-112

Vitt et al., 1997 L.J. Vitt, P.A. Zani, A.A.M. DeBarros Ecological variation among populations of the gekkonid lizard Gonatodes humeralis in the Amazon basin Copeia, 1997 (1997), pp. 32-43

Vitt et al., 2000 L.J. Vitt, R.A. Souza, S.S. Sartorius, T.C.S. Avila-Pires, M.C. Espósito Comparative ecology of sympatric Gonatodes (Squamata, Gekkonidae) in the western Amazon of Brazil Copeia, 2000 (2000), pp. 83-95

Welch and Bromham, 2005 J.J. Welch, L. Bromham Molecular dating when rates vary Trends Ecol. Evol., 20 (2005), pp. 320-327

Wesselingh and Salo, 2006 F.P. Wesselingh, J.A. Salo A miocene perspective on the evolution of the Amazon basin Scripta Geol., 133 (2006), pp. 439-458

Whinnett et al., 2005 A.

Whinnett, M. Zimmermann, K.R. Willmott, N. Herrera, R. Mallarino, F. Simpson, M. Joron, G. Lamas, J. M allet Strikingly variable divergence times inferred across an Amazonian butterfly 'suture zone' Proc. $R$. Soc. B, 272 (2005), pp. 2525-2533

Zachos et al., 2001 J. Zachos, M. Pagani, L. Sloan, E. Thomas, K. Billups Trends, rhythms, and aberrations in global climate 65Ma to present Science, 292 (2001), pp. 686-693

Zhang et al., 2006 P. Zhang, Y.Q. Chen, H. Zhou, Y.F. Liu, X.L. Wang, T.J. Papenfuss, D.B. Wake, L.H. Qu Phylogeny, evolution, and biogeography of Asiatic Salamanders (Hynobiidae) Proc. Natl. Acad. Sci. USA, 103 (2006), pp. 7360-7365 